\title{
Faktor Penyebab Indisipliner Siswa dalam Mematuhi Tata Tertib di Sekolah Dasar
}

\author{
Ria Anzalena
}

Universitas Bengkulu

riaanzalena1@gmail.com

Syahril Yusuf

Universitas Bengkulu

syahrilyusuf1115@yahoo.co.id

\section{Lukman}

Universitas Bengkulu

toplukman232@gmail.com

\begin{abstract}
This study aimed to describe the form-student disciplinary form, factors that cause indiscipline students and how to deal with indiscipline behavior of students in keeping order in the Primary School. The approach and type of research is descriptive qualitative. Subjects were high grade students who often do indiscipline in keeping order in the Primary School. The data collection techniques through observation, interviews and documentation. Credibility test data through triangulation. The data have been analyzed through data reduction, data presentation and conclusion. The results of this research are: 1) The form of disciplinary students to comply with the rules in elementary school are most often violated is in dress, students still often do not put clothes into the violations that are not observed are meroko school environment 2) Factors that cause behavior indiscipline students in keeping order in the Elementary School that is, a) internal factors and b) external factors which consisted of factors than others, economic factors and factors of social media, every student has different factors in conducting disciplinary, 3) How to deal with indiscipline Elementary School students has been implemented through the example and habituation. Based on the results of this study concluded that the causes of indiscipline every student is different to that teachers should increase attention to the students and always carry out the recording of the students who do indiscipline so that students are more disciplined and the rules and the penalties were further optimized in accordance with the development of students.
\end{abstract}

Keywords: Rules of Conduct, disciplinary, Students

\begin{abstract}
Abstrak
Penelitian ini bertujuan untuk mendeskripsikan bentuk-bentuk indisipliner siswa, faktor-faktor penyebab indisipliner siswa dan cara menangani perilaku indisipliner siswa dalam mematuhi tata tertib di Sekolah Dasar. Pendekatan dan jenis penelitian yang digunakan adalah deskriptif kualitatif. Subjek penelitian adalah siswa kelas tinggi yang sering melakukan indisipliner dalam mematuhi tata tertib di Sekolah Dasar. Teknik Pengumpulan data melalui observasi, wawancara dan
\end{abstract}


dokumentasi. Uji kredibilitas data melalui triangulasi. Data yang telah diperoleh dianalisis melalui reduksi data, penyajian data dan penarikan kesimpulan. Hasil penelitian ini yaitu: 1) Bentuk indisipliner siswa dalam mematuhi tata tertib di Sekolah Dasar yang paling sering dilanggar adalah dalam hal berpakaian, siswa masih sering tidak memasukkan baju kedalam, pelanggaran yang tidak teramati adalah meroko dilingkungan sekolah 2) Faktor-faktor yang menyebabkan perilaku indisipliner siswa dalam mematuhi tata tertib di Sekolah Dasar yaitu, a) Faktor internal dan b) Faktor eksternal yang terdiri dari faktor dari orang lain, faktor ekonomi dan faktor media sosial, setiap siswa memiliki faktor yang berbeda dalam melakukan indisipliner, 3) Cara menangani indisipliner siswa di Sekolah Dasar sudah terlaksana melalui keteladanan dan pembiasaan. Berdasarkan hasil penelitian dapat disimpulkan bahwa faktor penyebab indisipliner setiap siswa berbeda untuk itu sebaiknya guru meningkatkan perhatian terhadap siswa dan selalu melaksanakan pencatatan terhadap siswa yang melakukan indisipliner agar siswa lebih disiplin serta peraturan dan hukuman yang diberikan lebih dioptimalkan sesuai dengan perkembangan siswa.

\section{Kata kunci :Tata Tertib, Indisipliner, Siswa}

\section{Pendahuluan}

Sekolah sebagai sebuah lembaga pendidikan merupakan salah satu lembaga yang bertanggung jawab terhadap pembentukan karakter (character building), terutama karakter disiplin siswa. Pendidikan karakter sebaiknya diterapkan sejak usia Sekolah Dasar, karena pada usia tersebut dapat membentuk kebiasaan baik siswa hingga siswa menjadi teratur dan mampu mengelola waktu dengan tepat serta memiliki karakter lain yang diharapkan, untuk mensukseskan pendidikan karakter di sekolah menurut Mulyasa (2012: 15) perlu dilakukan identifikasi karakter, yang akan digunakan sebagai pilar perilaku bagi individu siswa, dan dilakukan sosialisasi mengenai pentingnya pendidikan karakter dengan tepat kepada siswa dari warga sekolah serta menciptakan lingkungan yang kondusif.

Secara umum Sekolah Dasar sudah menanamkan nilai-nilai karakter disiplin yang dapat membentuk siswa menjadi lebih tertib dan menjadikan siswa lebih teratur, serta berperilaku patuh dan tunduk terhadap peraturan yang berlaku, maksudnya kepatuhan dan kedisiplinan itu lebih ditekankan pada kesadaran diri siswa bukan karena paksaan. Nilai-nilai karakter memang beragam, namun dalam pembentukan karakter seseorang perlu memiliki kedisiplinan diri terlebih dahulu, agar dapat mengantarkan pada kebiasaan baik dan menuju kesuksesan dalam hidup, akan tetapi pada kenyataannya banyak perilaku disiplin siswa yang dilatarbelakangi karena adanya paksaan dan aturan yang mengekang, hal tersebut terlihat ketika siswa disiplin hanya didepan guru saja.

Menumbuhkan disiplin siswa sangat perlu untuk menyukseskan pendidikan karakter disekolah menurut Fathurohhman (2013: 128) disiplin adalah bisa mengerjakan sesuatu secara tertib, memanfaatkan waktu untuk melakukan kegiatan positif dalam belajar secara teratur, selalu mengerjakan sesuatu dengan penuh tanggung jawab, selalu belajar dan bekerja keras, mengetahui peraturan dan mematuhi tata tertib dalam lingkungan, menjaga ketertiban umum dan tata pergaulan secara bertanggung jawab, mematuhi norma yang berlaku di sekolah lingkungan keluarga maupun masyarakat untuk menjaga keutuhan lingkungan sosial, menghargai waktu, bekerja secara tuntas dan bertanggung jawab, biasa mematuhi tata tertib baik dilingkungan keluarga, masyarakat dan sekolah. 
Beberapa pelanggaran tata tertib sekolah yang dilanggar siswa Sekolah Dasar (SD) tersebut kebanyakan siswa dari kelas lima yang sudah lama mendapatkan pembelajaran disekolah yaitu lima tahun, tetapi masih saja melanggar tata tertib sekolah diantaranya terlambat datang ke sekolah, seragam sekolah tidaksesuai aturan, pakaian dikeluarkan dan tidak memakai ikat pinggang.

Sepatu berwarna selain ketentuan, model rambut yang tidak diperbolehkan, tidak mengerjakan tugas, serta aksesoris yang berlebihan, pelanggaran yang disebutkan tersebut memang tergolong ringan, tetapi tidak menutup kemungkinan jika dibiarkan lama-kelamaan akan menjadi kebiasaan siswa sehingga berlanjut ke tahap pendidikan yang lebih tinggi dan pelanggaran tersebut juga merupakan beberapayang membuat siswa kurang tertib sehingga menghambat proses pembelajaran.

\section{Metode}

Jenis penelitian yang digunakan dalam penelitian ini adalah deskriptif kualitatif, penelitian ini merupakan penelitian tentang data yang dikumpulkan dan dinyatakan dalam bentuk kata-kata dan gambar, kata-kata disusun dalam bentuk kalimat. Menurut Sukardi (2006: 62) dalam penelitian kualitatif, wawasan yang luas merupakan syarat yang perlu dilakukan oleh seorang peneliti guna mendalami teori yang relevan dengan permasalahan yang hendak dipecahkan. Penelitian kualitatif ditujukan untuk memahami fenomena-fenomena sosial dari sudut perspektif narasumber atau informan. Informan adalah orang-orang yang diajak berwawancara, diobservasi, dan diminta memberikan data.

Instrumen atau alat penelitian dalam penelitian kualitatif adalah peneliti sendiri. Karena penelitian ini instrumennya adalah peneliti sendiri maka fokus penelitian harus jelas, untuk itu akan dikembangkan instrumen penelitian sederhana berupa pedoman observasi berkaitan dengan rumusan masalah yang telah peneliti buat mengenai bentuk-bentuk indisipliner siswa, faktor penyebab indisipliner siswa dalam mematuhi tata tertib siswa di sekolah dan pedoman wawancara yang ditujukan kepada informan yaitu kepala sekolah, guru, siswa dan penjaga sekolah yang ada di SD Negeri 25 Kota Bengkulu mengenai karakter disiplin siswa seharihari disekolah.

Dalam penelitian ada beberapa macam teknik pengumpulan data, diantaranya yaitu: Instrument yang digunakan dalam penelitian ini adalah pedoman observasi dan pedoman wawancara, dengan demikian peneliti menggunakan observasi, wawancara, dan studi dokumentasi sebagai teknik pengumpulan data. Uji keabsahan data dengan triangulasi yaitu menggunakan triangulasi teknik dan sumber. Teknik analisis data menggunakan teknik analisis data model interaktif menurut Miles dan Huberman. Menurut Miles dan Huberman dalam Sugiyono (2014: 247) menjelaskan bahwa model ini terdiri atas empat tahapan yang harus dilakukan peneliti, yaitu tahap pengumpulan data, reduksi data, display data dan yang terakhir adalah tahap penarikan kesimpulan dan/atau tahap verifikasi.

\section{Hasil}

Deskripsi Hasil Penelitian

Berdasarkan observasi dan wawancara yang telah dilaksanakan peneliti, hasil penelitian yang berjudul faktor penyebab indisipliner siswa dalam mematuhi tata tertib di Sekolah Dasar. Menunjukkan bahwa penelitian ini, masih ada beberapa bentuk perilaku indisipliner atau ketidakdisiplinan siswa yang diamati. Khusus pada kelas tinggi. Untuk itu sesuai dengan lima indikator kisi-kisi instrumen, dapat dideskripsikan bentuk-bentuk indisipliner siswa dalam mematuhi tata tertib di Sekolah Dasar, yaitu : 
1) Kehadiran Siswa di Sekolah

Berdasarkan hasil analisis observasi pertama yang dilaksanakan peneliti pada hari senin tanggal 27 Maret 2017, mengenai kedatangan siswa ke sekolah harus tepat waktu. Kehadiran siswa sebelum kegiatan pembelajaran setiap hari dimulai sebelum pukul 07.30 WIB. Namun, faktanya masih ada beberapa siswa yang datang terlambat. Masih ada siswa yang datang setelah jam 07.30 lebih, baru tiba di sekolah. Padahal, setiap hari senin siswa harus melaksanakan kegiatan rutin upacara bendera terlebih dahulu sebelum pembelajaran kelas dimulai. Setelah diamati dari tujuh siswa yang terlambat.

2) Cara Berpakaian Siswa di Sekolah

Berdasarkan hasil analisis observasi dan wawancara mengenai berpakaian rapi kesekolah yang telah peneliti laksanakan dari tanggal 27 Maret 2017-24 April 2017. Bahwa masih terlihat perilaku indisipliner beberapa siswa yang diamati yaitu, tidak berpakaian seragam yang bersih, rapi dan sopan karena pakaian terlihat kurang rapi atau kusut, seperti belum disetrika serta tidak dikancing dan baju dikeluarkan atau tidak dimasukkan kedalam celana bagi siswa laki-laki dan rok bagi siswa perempuan.

3) Memelihara Fasilitas Umum Sekolah

Berdasarkan analisis hasil observasi dan wawancara maka mendapat Indikator ketiga yang peneliti amati adalah mengenai memelihara fasilitas umum. Siswa tidak diperbolehkan meminjam barang sekolah tanpa izin, seharusnya siswa menyiram, membersihkan WC yang telah digunakan, siswa dilarang mencoret-coret meja, kursi, lemari, dinding sekolah atau tempat lainnya yang ada disekolah. Namun, berdasarkan observasi tanggal 27 Maret - 24 April 2017 setiap hari senin siswa berebutan fasilitas alat musik untuk upacara, setelah meminjam dengan guru.

4) Melestarikan Lingkungan Sekolah

Berdasarkan analisis hasil observasi dan wawancara mengenai indikator disiplin selanjutnya yang peneliti amati tentang melestarikan lingkungan sekolah. Siswa tidak diperbolehkan merokok dilingkungan sekolah, memang tidak teramati hal demikian karena merokok merupakan pelanggaran yang sedikit berat di Sekolah Dasar.

5) Kebiasaan Mengikuti Kegiatan Sekolah

Berdasarkan hasil analisis observasi dan wawancara, indikator terakhir yang peneliti amati adalah mengenai kebiasaan tertib ketika mengikuti pelaksanaan kegiatan rutin di sekolah yaitu, kegiatan upacara bendera, tafakur dan senam pagi.

Ada pula perilaku indisipliner siswa yaitu tidak berdoa sebelum dan sesudah pembelajaran, bahkan siswa mengobrol dan mengganggu teman.

a. Faktor-Faktor Penyebab Indisipliner Siswa SD Negeri 25 Kota Bengkulu

Berdasarkan hasil analisis observasi dan wawancara yang telah peneliti laksanakan. Mulai tanggal 27 Maret- 24 April 2017, saat melakukan penelitian di Sekolah Dasar, terdapat faktor-faktor yang menyebabkan perilaku indisipliner siswa dalam mematuhi tata tertib di sekolah. hal tersebut sesuai dengan yang disampaikan Ibu RS sebagai kepala sekolah yang mengatakan bahwa sebagai seorang pendidik harus mempelajari apa yang menjadi penyebab siswa tidak disiplin, bisa berasal dari orang tua siswa sehingga dapat ditanyakan langsung pada orang tuanya.

1) Kehadiran Siswa di Sekolah

Berdasarkan analisis observasi dan wawancara yang telah peneliti amati. Sesuai dengan bentuk indisipliner siswa mengenai datang kesekolah yang tidak tepat waktu berdasarkan wawancara dengan RQ, keterlambatannya beralasan karena seragam yang harus dipakai, ditinggalkan dirumah nenek dibelakang sekolah, $R Q$ harus mengambilnya dulu sebelum datang kesekolah dan mengganti baju disana sehingga ia terlambat datang kesekolah. Seperti yang dikatakan oleh RQ. Bahwa RQ harus mengambil baju dirumah neneknya terlebih dahulu, karena pada minggu 
sebelumnya meninggalkan baju seragam disana saat mampir dan langsung mengganti baju.

Tidak mengirim surat keterangan ketika tidak hadir kesekolah termasuk perilaku indisipliner siswa, faktor penyebab siswa tidak mengirim surat adalah adanya orang tua/ wali siswa yang sibuk dengan pekerjaan dan ada pula wali siswa sendiri yang datang kesekolah tanpa memberi surat keterangan karena tidak mengerti menulis surat izin ataupun surat keterangan lainnya.

2) Cara Berpakaian Siswa di Sekolah

Berdasarkan analisis observasi dan wawancara yang telah peneliti amati. Faktor penyebab berikutnya mengenai berpakaian kurang rapi di SD Negeri 25 Kota Bengkulu. Seperti yang telah dijelaskan sebelumya berdasarkan observasi RQ menggunakan baju kusut dikarenakan baru ambil dari rumah neneknya, sehingga baju tersebut memang belum disetrika dan langsung digunakan untuk dipakai kesekolah.

3) Memelihara Fasilitas Umum Sekolah

Berdasarkan analisis observasi dan wawancara yang telah peneliti amati. Faktor penyebab ketiga mengenai memelihara fasilitas umum disekolah SD Negeri 25 Kota bengkulu yang seharusnya meminta izin terlebih dahulu sebelum menggunakan, siswa memang meminta izin terlebih dahulu. Namun, berdasarkan observasi pada hari senin tanggal 27 maret 2017 teramati siswa berebutan alat drum yang dipinjam untuk dimainkan. Penyebabnya adalah siswa penasaran dengan alat tersebut dan ingin memainkannya.

4) Melestarikan Lingkungan Sekolah

Berdasarkan analisis observasi dan wawancara yang telah peneliti amati. Faktor penyebab indisipliner siswa yang keempat mengenai melestarikan lingkungan sekitar yang ada di sekolah, pertama siswa tidak diperbolehkan merokok dilingkungan sekolah tampaknya memang tidak ada siswa SD yang merokok di SD Negeri 25 Kota Bengkulu. Namun, siswa AR mengaku pernah merokok dilingkungan rumahnya itu pun hanya sekali dan ikut ikutan temannya yang sudah SMP. Kedua, makan dan minum di dalam ruangan juga termasuk perilaku indisipliner siswa, penyebab siswa senang makan dan minum di ruang kelas adalah karena dikantin SD Negeri 25 Kota Bengkulu tidak memiliki bangku sehingga siswa makan dan minum di dalam ruangan karena lebih santai dan dapat duduk dengan tenang hal tersebut disampaikan APS dan SS siswi kelas VA, yang kedapatan sedang makan dan minum di dalam ruangan.

5) Kebiasaan saat Mengikuti Kegiatan Sekolah

Berdasarkan analisis observasi dan wawancara yang telah peneliti amati. Faktor penyebab siswa masih tidak tertib adalah, ketika upacara masih ada siswa yang merasa bosan dan akhirnya mengganggu teman, mengajak teman mengobrol dan ikut-ikutan teman lainnya, walaupun guru sudah menegurnya dan memberikan peringatan kepada siswa berulang kali, tetapi siswa berinisial AM dan AA tetap saja ribut. AM menyenggol SS yang sedang menyimak guru menyampaikan amanah pada saat kegiatan upacara bendera dan AA menggangu AT dengan cara mencuil pundak AT, kemudian AT membalas cuilan AA lalu mereka saling mengganggu satu sama lain dan siswa atau teman-temannya yang melihat mengikuti perilaku indisipliner tersebut.

b. Cara Menangani Indisipliner Siswa di SD Negeri 25 Kota Bengkulu

Dari beberapa hasil yang telah dianalisis mengenai bentuk-bentuk perilaku indisipliner siswa dan faktor- faktor penyebab perilaku indisipliner siswa tersebut, maka siswa yang tidak atau kurang disiplin diberi tindakan baik secara preventif maupun reprensif guna menangani indisiplinernya, antara lain:

1) Membentuk Keteladanan dan Kebiasaan yang Baik bagi Siswa

Membentuk keteladanan yang baik merupakan cara menangani indisipliner yang utama dan di SD Negeri 25 Kota Bengkulu menerapkan 7K (kebersihan, kerapian, kekeluargaan, kesopanan, keindahan, kesantunan dan kerindangan) dengan hal itu 
pula siswa dibiasakan setiap hari diberi motivasi dari guru yang ada di sekolah. Contohnya: guru berpakaian yang rapi dan ketika siswa akan masuk ke gerbang sekolah langsung disambut guru dengan bersalaman, hal tersebut merupakan keteladanan dan setiap hari dilaksanakan oleh beberapa guru guna menjadi pembiasaan yang tertib bagi siswa di SD Negeri 25 Kota Bengkulu. Siswa juga diberi tanggung jawab untuk membersihkan kelas dengan mengatur jadwal kelas masing masing, dibiasakan pula setiap hari sabtu kebersihan dan gotong royong membersihkan sekolah.

2) Memberikan Peringatan Kepada Siswa

Teramati siswa diberi nasehat yang membuat siswa sadar pentingnya berdisiplin. Meskipun belum seluruh siswa yang memahami dan mengerti dengan nasehat yang telah diberikan. Untuk itu sering terlihat ketika mengobservasi guru memberikan peringatan dengan mengatakan kepada siswa jangan mengulanginya lagi, jika tidak mau orang tua dipanggil, peringatan tersebut diberikan kepada siswa indisipiliner agar siswa mampu memperbaiki kesalahannya. Peringatan dan ancaman berbeda jika peringatan berarti guru mengingatkan siswa tentang kesalahannya dan solusi yang harus diambi sedangkan ancaman dapat menggangu kesehatan psikis siswa.

3) Mencatat Siswa

Siswa yang sering ribut atau melanggar peraturan biasanya dicatat baik dicatat dengan guru ataupun dengan ketua kelas yang mengatur kelas, hal tersebut terjadi ketika peneliti memasuki ruang kelas yang tidak ada guru, sehingga guru memerintahkan ketua kelas untuk mencatat siapa teman-teman yang terlihat tidak mengerjakan tugas dan main-main ketika pembelajaran berlangsung. Hal tersebut juga merupakan cara menangani perilaku indisipliner siswa meski tidak secara keseluruhan siswa yang menerima namanya dicatat ketua kelas, karena kebanyakan siswa yang di tinggal guru akan ribut.

4) Memberikan Hukuman yang Mendidik Kepada Siswa

Memberikan hukuman yang mendidik kepada siswa juga termasuk cara untuk menangani perilaku indisipliner, jika hanya dengan memberikan peringatan dan teguran siswa masih terus mengulangi tindakan indisiplinernya maka terlihat siswa diberikan hukuman.

\section{Pembahasan}

Karakter disiplin sangat diperlukan dalam dunia pendidikan dikarenakan dapat mencapai kesuksesan siswa dengan baik. Hal tersebut sesuai dengan pendapat Saptono (2011: 23) "Pendidikan karakter adalah upaya yang dilakukan dengan sengaja untuk mengembangkan karakter baik (good character)". Dengan demikian pendidikan karakter disiplin perlu dikembangkan pada diri setiap siswa agar menjadikan siswa pribadi yang lebih taat dan terampil.

Berdasarkan hasil observasi, wawancara dan dokumentasi yang telah dilaksanakan peneliti pada tanggal 27 Maret hingga tanggal 24 April 2017 berikut pemaparannya mengenai bentuk-bentuk perilaku indisipliner siswa :

1) Kehadiran siswa di sekolah

Kehadiran siswa adalah indikator pertama yang harus dimiliki dalam disiplin dan kedatangan siswa yang terlambat termasuk indisipliner siswa, karena termasuk perilaku kurang disiplin dalam penggunaan waktu. Hal tersebut sesuai dengan pandangan Ruswandi (2013: 185) mengenai macam-macam disiplin salah satunya adalah disiplin dalam penggunaan waktu, waktu sangatlah berharga karena waktu yang telah berlalu tidak akan kembali lagi. Kedatangan siswa sangat penting agar tidak mengganggu kegiatan yang ada disekolah Berdasarkan hasil observasi yang telah dilaksanakan peneliti pada tanggal 27 Maret- 24 April 2017. Peneliti mengamati ada beberapa orang siswa yang sering datang terlambat kesekolah. Terutama pada siswa kelas V setelah diwawancarai ternyata ada beberapa faktor yang menyebabkan siswa melakukan indisipliner. 
2) Mengerjakan tugas piket dengan regu kerja sebelum bel masuk

Pada hari yang sama ketika peneliti mengamati ruang kelas V SD Negeri 25 Kota Bengkulu terlihat bersih, karena salah seorang siswa mengatakan setiap hari sabtu seluruh siswa melaksanakan kebersihan sehingga siswa yang piket kelas pada hari senin tidak terlalu terbebani dengan tugas piket dan hanya menyiram bunga atau membuang sampah saja. Namun, pada hari lainnya masih ada siswa tidak mau mengerjakan tugas piket bersama-sam dengan regu piket kelas lainnya dikarenakan malas. Hal tersebut berkaitan dengan pendapat Ruswandi (2013: 184) setiap orang memiliki disiplin diri dan tingkat disiplin berbeda". Dengan demikian berarti memang tidak akan semua siswa memiliki disiplin yang sama tinggi melainkan akan ada siswa yang memiliki disiplin diri yang rendah.

3) Jika terlambat melapor dengan guru piket

Beberapa siswa yang datang terlambat tiba di sekolah, tidak melapor dengan guru piket terlebih dahulu hal tersebut termasuk kedalam perilaku indisipliner siswa dalam mematuhi tata tertib di sekolah karena tercantum dalam peraturan atau tata tertib sekolah.

a. Indisipliner dalam hal Berpakaian

1) Berpakaian seragam kurang rapi, bersih dan sopan

Berdasarkan pengamatan yang telah peneliti laksanakan memang kebanyakan siswa sudah menggunakan pakaian seragam rapi, bersih dan sopan namun masih ada siswa yang memakai pakaian yang kusut serta lengan baju digulung dan pakaian tidak dimasukkan kedalam celana bagi siswa laki-laki atau rok siswa bagi siswa perempuan. Berpakaian kurang rapi, bersih dan sopan termasuk kealam disiplin yang kecil dan kurang diperhatikan, berkaitan dengan pendapat Ruswandi (2013: 189) yang mengatakan bahwa menerapkan disiplin sebaiknya dimulai dari sesuatu yang kecil, karena merupakan langkah awal untuk meraih sesuatu yang besar.

2) Berseragam

Berdasarkan hasil observasi ada siswa yang menggunakan pakaian yang tidak seragam dan sesuai dengan ketentuan harinya. Setiap hari kamis seharusnya menggunakan pakaian batik, namun ada seorang siswa menggunakan pakaian merah putih faktornya adalah bahwa siswa mengaku orang tua yang mencuci baju batiknya sehingga dia tidak bisa menggunakan baju seragam batik ke sekolah.

3) Memakai perhiasan yang berlebihan

Beberapa siswa menggunakan catkuku dan gelang yang banyak ketika di wawancara ternyata siswa mencari perhatian dan mengaku agar terlihat cantik, ada pula siswa laki-laki yang menggunakan cincin batu giok dan ketika ditanya apakah boleh dengan gurunya mereka menjawab tidak apa-apa. Asalkan tidak ketahuan oleh ibu guru.

b. Indisipliner dalam hal Memelihara Fasilitas Umum

1) Meminta izin

Sebelum menggunakan fasilitas seperti drum untuk upacara siswa harus meminta izin terlebih dahulu, tujuannya agar siswa tidak mencuri dan tidak hilang. Selain memelihara siswa juga harus bertanggung jawab dengan fasilitas yang siswa pinjam. Namun, masih ada siswa yang berebutan ingin menggunakan alat sekolah tersebut seperti berupa drum, naskah upacara, speaker, penggaris sekolah dll.

2) Tidak merusak dan mencoret-coret fasilitas

Kenyataannya dilapangan siswa masih saja ada yang melakukan hal tersebut. Mencoret-coret meja dengan menggunakan alat tulis berupa pena, pensil dan tipeks. Guru yang menyaksikan hal tersebut akan langsung menegur dan menasehati siswa dengan mengatakan jika merusak fasilitas sekolah maka harus memperbaiki atau menggantinya.

c. Indisipliner dalam hal Melestarikan Lingkungan

1) Makan dan minum didalam kelas 
Makan dan minum didalam kelas akan menyebabkan kelas menjadi kotor dan tidak nyaman digunakan untuk pembelajaran sehingga pembelajaran menjadi kurang kondusif.

2) Membuang sampah sembarangan

Dampak yang akan terjadi jika membuang sampah tidak pada tempatnya dapat membuat sekolah menjadi tempat yang kurang nyaman. Selain itu ada pula siswa yang terlihat masih belum melestarikan lingkungan dengan berlaku diantaranya mencabut tanaman dan memetiknya. Terkadang siswa melakukan hal tersebut tidak di sengaja karena sedang duduk duduk di dekst tanaman. Dan tangannya memegang daun serta langsung memetiknya.

d. Indisipliner dalam hal Kebiasaan Ketika Mengikuti Kegiatan Sekolah

1) Siswa tidak berdo'a

Masih ada siswa yang tidak berdo'a sebelum pembelajaran dimulai, siswa yang tidak berdoa didalam kelastermasuk dalam perilaku indisipliner dalam beribadah karena sesuai dengan pendapat ruswandi mengenai macam-macam disiplin salah satunya megenai disiplin dalam beribadah. Meski telah diberi teguran terhadap gurunya.

2) Mengikuti jam belajar dengan aktif

Belum keseluruhan siswa yang mengikuti pembelajaran secara aktif, ada siswa yang mengobrol dan bisik-bisik dengan temannya ketika pembelajaran berlangsung atau ketika guru sedang menjelaskan pelajaran yang menyebabkan siswa ketika diberi pertanyaan siswa tidak bisa menjawabnya.

3) Tidak Melaksanakan PR

Ketika pembelajaran berlangsung ada juga siswa yang tidak membuat tugas sekolah dengan demikian siswa telah melakukan indisipliner dalam hal kehidupan pribadinya karena tugas atau PR (pekerjaan rumah) yang dibuat untuk menbuat siswa lebih giat belajar.

4) Mengikuti kegiatan disekolah

1. Faktor-faktor Penyebab Indisipliner Siswa

Indisipliner siswa merupakan tindakan atau perilaku yang tidak baik apalagi dalam mematuhi tata tertib sekolah yang mengarah pada kondusif dan kenyaman sekolah. Indisipliner tidak hanya memperburuk diri sendiri tetapi juga orang lain. Jika ada siswa yang melakukan indisipliner, perilaku ini bukanlah hal yang timbul begitu saja, namun ada faktor yang menyebabkan indisipliner serta banyak hal yang mempengaruhinya. Seorang siswa bisa saja tidak mau melakukan indisipliner. Namun, jika satu dan hal yang lain menjadi pemicunya tetap siswa melakukan pelanggaran peraturan atau tidak disiplin sehingga berperilaku indisipliner. Untuk itu mengetahui faktor- faktor yang menjadi penyebab dari indisipliner siswa dalam mematuhi tata tertib disekolah adalah salah satu cara untuk membut siswa menjadi lebih disiplin.

Adapun dari hasil perilaku indisipliner siswa dalam mematuhi tata tertib di Sekolah Dasar tersebut memiliki banyak faktor yang mempengaruhi dan menyebabkan siswa melakukan perilaku indisipliner tersebut, untuk itu peneliti membagi menjadi empat faktor, yaitu :

\section{a. Faktor Internal}

Faktor internal adalah faktor yang berasal dari dalam diri siswa itu sendiri. Misalnya keinginan dari diri siswa sendiri untuk melakukan perilaku indisipliner atau ketidakdisiplinan disekolah tanpa memperdulikan dampaknya bagi orang lain atau pun dirinya sendiri. Bisa pula yang diakibatkan karena ketidakpahaman siswa mengenai tata tertib yang harus dipatuhi sehingga mengakibatkan siswa tidak disiplin. Ada pula penyebab karena siswa terlalu menganggap sepele perilaku indisipliner dan menganggap perilaku indisipliner hal yang mudah atau menganggap indisipliner dalam pelanggaran kecil sehingga tidak ada kemauan untuk memperbaiki diri. Tetapi faktor internal atau faktor dari dalam diri siswa ini 
agak sulit untuk di ketahui apakah benar dari siswa itu sendiri atau karena fakor lainnya. Karena siswa harus melalui pengamatan yang lebih mendalam dan harus diamati keseharian siswa tersebut.

b. Faktor Eksternal

Faktor Kebutuhan ekonomi dapat pula menjadi penyebab siswa melakukan perilaku indisipliner misalkan baju yang tidak dimasukkan, karena baju siswa yang sudah tidak muat lagi atau kekecilan sedangkan orang tuanya tidak memiliki uang untuk membeli baju baru yang layak pakai sehingga menjadi penyebab siswa tidak berpakaian rapi. Mematuhi tata tertib dikarenakan adanya faktor-faktor penyebab baik secara internal maupun eksternal. Indikator faktor penyebab siswa melakukan indisipliner dapat dilihat melalui indikator karakter disiplin dalam mematuhi tata tertib sekolah.

2. Cara Menangani Indisipliner Siswa

Perilaku indisipliner siswa tersebut, diberi tindakan dan telah ditangani sekolah oleh pemimpin sekolah dan stakeholder yang ada di sekolah baik secara preventif maupun reprensif diantaranya, yaitu:

a. Membentuk Keteladanan

Untuk menjadi guru yang profesional harus mampu mejadi teladan yang baik bagi siswa, karena menurut Mulyasa (2012: 166) Pribadi guru memiliki andil yang sangat besar terhadap keberhasilan pendidikan, terutama dalam pendidikan karakter disiplin, yang sangat berperan dalam membentuk pribadi dan karakter disiplin siswa lebih taat dan patuh terhadap peraturan di sekolah. Karena siswa masih suka mencontoh, termasuk siswa mencontoh pribadi gurunya dalam membentuk kepribadian diri. Termasuk seorang siswa Sekolah Dasar yang masih suka meniru perilaku orang tua atau guru sebagai orang tua di sekolah.

b. Memberikan Peringatan Kepada Siswa

Memberikan peringatan kepada siswa, agar dapat memberantas tindak indisipliner siswa secara tuntas tidak bisa dilakukan secara parsial atau setengasetengah, tetapi harus secara total dan sistematis. Hal ini hanya mungkin berhasil melalui penerapan yang ada di sekolah oleh pemimpin sekolah atau kepala sekolah dan guru. Serta seluruh stakeholder yang berada dilingkungan sekolah. Peringatan tersebut dapat berupa nasihat yang diberikan guru kepada siswa yang melakukan perilaku indisipliner.

c. Mencatat Siswa

Jika masih ada siswa yang melakukan indisipliner sebaiknya dicatat agar guru lebih mengingat siswa yang telah dan sering melakukan Indisipliner atau pelanggaran dan sudah berapa kali siswa tersebut melakukan indisipliner di sekolah, sehingga guru mampu menanyakan langsung kepada orangtua/ wali siswa dan mencari tahu mengapa hal tersebut terjadi dan apa hal yang harus dilakukan agar siswa tidak mengulangi perilaku indisiplinernya tersebut.

d. Memberikan Hukuman

Hukuman yang diberikan kepada siswa bukanlah hukuman yang menyakitkan atau hukuman seperti pukulan yang akan mengganggu psikis siswa. Tetapi memberikan hukuman mendidik seperti siswa yang terlambat dihukum dengan cara memungut sampah terlebih dahulu, setelah itu baru boleh mengikuti pembelajaran di kelas. Dengan demikian seharusnya siswa mampu berfikir bahwa sebagai seorang siswa harus datang tepat waktu dan tidak mengulanginya lagi, begitupun untuk bentuk perilaku indisipliner lainnya, sudah semestinya siswa diberikan hukuman atau sanksi sesuai dengan pelanggaran yang dilakukan siswa. Mulai dari yang ringan, sedang hingga hukuman yang berat.

\section{Simpulan}

Berdasarkan analisis hasil dan pembahasan mengenai penelitian yang telah dilaksanakan dari tanggal 27 Maret-24 April 2017, maka dapat disimpulkan bahwa faktanya setiap hari selalu ada siswa yang melakukan indisipliner di sekolah dengan 
berbagai macam bentuk yang beragam. Pelanggaran yang paling sering dilakukan oleh siswa adalah mengenai indisipliner dalam hal berpakaian, setiap hari selalu ada siswa yang melakukan indisipliner dengan baju yang dikeluarkan. Dan bentuk pelanggaran yang tidak pernah terlihat adalah mengenai merokok dilingkungan sekolah.

Indisipliner siswa di Sekolah ada dua faktor yaitu, faktor internal atau yang berasal dari diri siswa sendiri dan faktor eksternal atau faktor yang berasal dari luar diri siswa yang terdiri dari faktor orang lain, faktor ekonomi dan faktor media informasi, adanya bentuk indisipliner dalam hal berpakaian setiap hari dikarenakan pakaian yang sudah tidak muat lagi dipakai dan siswa tidak mampu untuk membeli pakaian seragam sekolah, ada pula siswa yang merasa kepanasan mengakibatkan baju dikeluarkannya.

\section{Saran}

Berdasarkan kesimpulan hasil observasi penelitian yang telah diperoleh, peneliti bermaksud memberikan saran, yakni:

1. Kepala Sekolah

Kepala sekolah seharusnya lebih meningkatkan manajemen sekolah, memberikan ketegasan dan pengawasan terhadap tata tertib dan pelanggaran yang dilakukan siswa.

2. Guru

Setiap guru diharapkan meningkatkan perhatian terhadap siswa dan selalu melaksanakan pencatatan terhadap siswa yang melakukan indisipliner agar siswa lebih disiplin serta peraturan dan hukuman yang diberikan lebih dioptimalkan sesuai dengan perkembangan siswa.

\section{Referensi}

Fathurrohman, P. dkk. 2013. Pengembangan Pendidikan Karakter. Bandung: Refika Aditama.

Kesuma, D. dkk. 2011. Pendidikan Karakter Kajian Teori dan Praktek di Sekolah. Bandung: PT Remaja Rosdakarya.

Koesoema, D. 2010. Pendidikan Karakter Strategi Mendidik Anak di Zaman Global. Jakarta: Grasindo.

Kurniawan, S. 2016. Pendidikan Karakter Konsepsi dan Implementasi secara terpadu di lingkungan keluarga, sekolah dan masyarakat. Yogyakarta: Arruzz Media

Mulyasa, E. 2012. Manajemen Pendidikan Karakter.Jakarta: Bumi Aksara

Rohman, M. 2012. Kurikulum Berkarakter. Jakarta : Prestasi Putra Karya.

Ruswandi. 2013. Psikologi Pembelajaran. Bandung: Cipta Pesona Sejahtera.

Saptono. 2011. Dimensi-dimensi Pendidikan Karakter. Jakarta: Erlangga Group.

Sugiyono. 2014. Metode Penelitian Kuantitatif Kualitatif dan R\&D. Bandung: Alfabeta.

Sukardi. 2006. Penelitian Kualitatif Naturalistik dalam Pendidikan. Yogyakarta: Usaha Keluarga. 